https://doi.org/10.30910/turkjans.633607

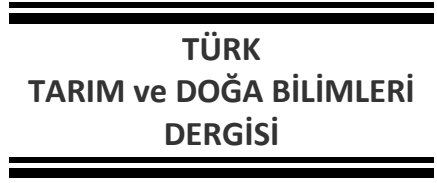

\section{Research Article}

TURKISH

JOURNAL Of AGRICULTURAL

and NATURAL SCIENCES

www.dergipark.gov.tr/turkjans

The Share of Subsidies in Income of Cereals Farmers in Turkey

\author{
Günay KELEŞ ${ }^{1 *}$, Serpil YILMAZ²
}

${ }^{1} \mathrm{NKU}$, Agricultural Faculty, Department of Agricultural Economics, Tekirdağ, Turkey

${ }^{2}$ Akdeniz University, Fisheries Faculty, Department of Basic Aquatic Science, Antalya, Turkey

*Corresponding author: gunaygungor99@gmail.com

Received: 30.04.2019

Received in Revised: 04.07.2019

Accepted: 02.09.2019

\begin{abstract}
Just as in the world, agriculture is also supported in various forms in Turkey. Agricultural subsidies in Turkey are land based subsidies, the difference payment system, animal husbandry subsidies, agricultural insurance subsidies, compensatory subsidies, other agricultural subsidies and interest-discounted agricultural loans. Commonly used field based agricultural supports; Support applied to hazelnut producers, good agricultural practices, organic agriculture and inputs supported by diesel, fertilizer and soil analysis. Supports for field crops are input support, agricultural credit and certified seed use support. In Turkey, agricultural subsidies are extremely important for producers. Because agricultural support is one of the basic tools used to increase farmer's income and hence agricultural producer welfare. For this, the share of agricultural subsidies in farmer incomes should be sufficient. In our country, agricultural subsidies do not get enough share from the state budget. In the Agricultural Law which was issued in 2006, it was decided that the support for farming will not be less than $1 \%$ of the national income rate. However, the farmers were only able to take half of this support. It is necessary to increase the share of the budget allocated to agricultural subsidies and thus the agricultural subsidies received by the producers. Therefore, in this study, the effects of the support policies applied in wheat, sunflower, paddy and canola products in the Thrace Region were examined. In this context, Thrace Region was selected to analyze the share of the support in the agricultural products in the farmer's income. Thrace Region, the most productive of our country I-II and III. Class has $73.8 \%$ of agricultural land.
\end{abstract}

Key words: Agricultural supports, agricultural policies, farmers income, Thrace region.

\title{
Türkiye'de Tarla Ürünlerinde Desteklemelerin Çiftçi Gelirleri İçindeki Payı
}

\begin{abstract}
Özet
Tüm dünyada olduğu gibi, Türkiye'de de tarım çeşitli şekillerde desteklenmektedir. Türkiye'deki desteklemeler; alan bazlı destekler, hayvancılık destekleri, tarım sigortası desteği, telafi edici ödeme destekleri, faiz indirimli tarımsal krediler, fark ödemesi şeklinde destekler ve diğer tarımsal amaçlı desteklerler olarak sıralanabilir. Yaygın olarak kullanılan alan bazlı tarımsal desteklemeler; fındık üreticilerine alternatif ürün desteği, iyi tarım uygulamaları, organik tarım ve mazot, gübre ve toprak analizi şeklinde uygulanan girdi destekleridir. Tarla bitkilerinde uygulanan destekler ise girdi desteği, tarımsal kredi ve sertifikalı tohum kullanımı destekleridir. Ülkemizde tarımsal desteklemeler üreticiler için son derece önemlidir. Çünkü tarımsal desteklemeler çiftçi gelirlerinin, dolayısıyla tarım üreticisinin refahının artırılması için kullanılan temel araçlardandır. Bunun için tarımsal desteklemelerin çiftçi gelirleri içerisindeki payının yeterli olması gerekmektedir. Ancak Türkiye'de tarımsal destekler devlet bütçesinden yeterince pay alamamaktadır. Nitekim, 2006 yılında çıkarılan Tarım Kanununda çiftçiye verilecek desteklerin milli gelire oranının \%1'den az olamayacağı hükme bağlanmış, üreticiler bu desteğin ancak yarısını alabilmişlerdir. Oysa üretim miktarının ve üretici refahının artırılması, tarımsal desteklemelere ayrılan payların ve dolayısıyla üreticilerin aldıkları tarımsal destekleme miktarlarının yeterliliğiyle mümkündür. Bu nedenle bu çalışmada, Trakya Bölgesi'nde en fazla üretimin gerçekleştirildiği buğday, ayçiçeği, çeltik ve kanola ürünlerinde uygulanan destekleme politikalarının etkileri irdelenmiştir. Bu kapsamda başlıca tarla
\end{abstract}


ürünlerinde ki desteklemelerin, çiftçi gelirleri içindeki payını analiz etmek için Trakya Bölgesi seçilmiştir. Trakya Bölgesi, Ülkemizin en verimli I-II ve III. sınıf tarım topraklarının \% 73,8'ine sahiptir.

Anahtar kelimeler: Tarımsal destekler, Tarım politikası, çiftçi gelirleri, Trakya bölgesi.

\section{Introduction}

Agriculture is supported in every country all over the world. The reasons of agricultural supporting policies are; the specific nature of agricultural production, its dependence on natural conditions and mostly affected by climate change, the large number of risks and uncertainties, the significant amount of population lived and employed in this sector, the low level of income and education etc.. The main objective of agricultural support policy is; to contribute to the solution of the priority problems of the agricultural sector, to increase the effectiveness of the policies implemented and to facilitate the harmonization of this policy within the sector. Agriculture is very important for all countries because our basic needs are produced in this sector. Since agricultural products have a strategic position, each country aims to be self-sufficient in agriculture and not to apply for import as much as possible. For these reasons, agriculture is one of the most protected areas in all countries.

In Turkey, the support policies for the agricultural sector have been implemented for many years with the base price and subsidy purchases. Later on, support was provided to the agricultural sector through applications such as input subsidies, low interest loans, premium payments, animal husbandry incentives and compensation payments to encourage the transition to alternative products and restricting planting areas on certain products. The state supports agricultural sector with the price policy in generally. However, these agriculture policies were implemented without solving the important structural problems of the agriculture of Turkey and therefore they could not reach their targets completely. This situation causes negatively affects to efficiency of agricultural policies and also brings an additional burden to the government budget.

In this study, the share of field crop subsidies in farmer incomes was studied to analyze the effects of supports in crop farms. The most important subsistence source of Thrace Region, which is Turkey's gateway to Europe, is agriculture and agriculture base industry. According to the TURKSTAT data, $79,13 \%$ of the agricultural production value of the region is obtained from vegetable production and $20,87 \%$ from animal production. The region is extremely suitable for agriculture in terms of climate and soil conditions. In crop and animal production yields are above the average in Turkey. The most important crops in the region are wheat, sunflower and paddy. In addition, planting of canola seeds, widely planted throughout the world, has been extensively planted in Turkey and especially in Thrace region in recent years. As in other regions, producers in the Thrace region are supported with different ways. Therefore, three provinces in Thrace Region (Tekirdağ, Kırklareli and Edirne) were investigated.

\section{Material and Methods}

In Thrace region (TR21), a total of 78.315 farmers are engaged in agricultural activities in the field (4.747.171 da) and at an average of $100 \mathrm{da}$ farms. When the statistics are examined, field crops are produced at a rate $95.4 \%$ on these lands. For this reason, TR 21 Region (Tekirdağ, Edirne and Kırklareli), which were mainly taken up in the regional surveys of TURKSTAT, were selected as the research area. The income levels of regional producers have been determined by using the questionnaire prepared with wheat, sunflower, canola and paddy producers.

The main material of the study was based on primary and secondary data. In obtaining the data, a non-probability sampling method had been adopted. Non-selective samples can be done in three ways as; Systematic, purposeful and appropriate sampling. The non-probability sampling method is also referred to as non-random sampling method in literature. Three forms of non-arbitrary sampling were taken into consideration to determine the number of producers surveyed.

Measures of the groups for the wheat, sunflower and canola farms were designated as; Group 1 (50-100 da), Group 2 (101-150 da), Group 3 (151-250 da) and Group 4 (more than $250 \mathrm{da})$. For Paddy, groups were designed as; Group 1 (Smaller than $100 \mathrm{da}$ ), Group 2 (101-250 da), Group 3 (251500da) and Group 4 (larger than $500 \mathrm{da}$ ).

Total of 144 questionnaires were conducted to realize research. In the selection, the production amounts of the provinces were taken into consideration and chosen 48 farmers from each provinces.

\section{Results and Discussion}

Agricultural policies implemented from the beginning of the 2000s since the Planned Period. Products supports are in the form of input subsidies and low-interest loans in Turkey generally. Within the scope of the Agricultural Reform 
Implementation Project after the 2000s, the fieldbased supports and rural development policies came into the agenda. With the aforementioned supports, it was aimed to ensure continuity of production, a stable income level of farmers, to protect the environment, to ensure food safety and to achieve the desired levels of efficiency (Tuncer and Günay, 2017). As a matter of fact, it has been found in the studies, the support payments are effective in many areas such as production quantity, product price, plantation area, land value and labor cost (Bayraktar and Bulut, 2016). To date, all countries have supported the agricultural sector in a variety of ways in order to achieve agricultural policy objectives (Yılmaz and etc., 1999). It has been found that many benefits for producers and productivity occur because of agricultural support. Indeed, a study by Weber and Key conducted in the US, it was found that every $1 \%$ increase in agricultural support resulted in an increase of $0,20 \%$ in production and a $0,19 \%$ increase in cultivation area (Weber and Key, 2012). Again in a study by Burfisher and Hopkins, it was determined that agricultural supports increased the welfare of producers and had more impacts on farmers' decisions such as consumption, savings and investment (Burfisher and Hopkins, 2003). Another article investigating the impact of agricultural supports on the labor market. It was concluded that the increase in agricultural support had a positive effect on agricultural employment (Goodwin and etc., 2007). Because of these benefits of agricultural supports and the fact that agriculture depends on natural conditions and therefore carry a lot of risks, agricultural sector have been supported by the public all over the world. Increasing agricultural support in Turkey, which has a $2 \%$ share of the budget, will ensure the competitiveness of the agricultural sector (Table 1).

Table 1. Share of agricultural support payments within the budget in Turkey

\begin{tabular}{cccccccccccc}
\hline Support payments & $\mathbf{2 0 0 6}$ & $\mathbf{2 0 0 7}$ & $\mathbf{2 0 0 8}$ & $\mathbf{2 0 0 9}$ & $\mathbf{2 0 1 0}$ & $\mathbf{2 0 1 1}$ & $\mathbf{2 0 1 2}$ & $\mathbf{2 0 1 3}$ & $\mathbf{2 0 1 4}$ & $\mathbf{2 0 1 5}$ & $\mathbf{2 0 1 6}$ \\
\hline $\begin{array}{c}\text { Agricultural support } \\
\text { payments (million TL) } \\
\text { Share of agricultural }\end{array}$ & 4747 & 5555 & 5809 & 4495 & 5817 & 6961 & 7553 & 8684 & 9148 & 9971 & 11489 \\
$\begin{array}{c}\text { support payments in } \\
\text { GDP (\%) }\end{array}$ & 0.6 & 0.6 & 0.6 & 0.4 & 0.5 & 0.5 & 0.5 & 0.5 & 0.4 & 0.4 & 0.4 \\
$\begin{array}{c}\text { Share of agricultural } \\
\text { support payments in } \\
\text { central budget (\%) }\end{array}$ & 2.7 & 2.7 & 2.6 & 1.7 & 2 & 2.2 & 2.1 & 2.1 & 2 & 2 & 2 \\
\hline
\end{tabular}

Source: http://www.bumko.gov.tr, 2016.

\section{Amounts of some products in Thrace region}

In the provinces of Tekirdağ, Edirne and Kırklareli, agriculture is one of the important income source. The most important crops are wheat, sunflower, rice and canola in the region. According to the Provincial Directorates of Agriculture, the minimum and maximum values of the average wheat, sunflower, canola and paddy yields of the enterprises are shown in Table 2. As you can see from the chart, there are big productivity differences between provinces. For example, wheat yield in Tekirdag province changes from $300 \mathrm{~kg} / \mathrm{da}$ to $800 \mathrm{~kg} / \mathrm{da}$, while wheat yield in Kırklareli province ranged from $270 \mathrm{Kg} / \mathrm{da}$ to $750 \mathrm{Kg} / \mathrm{da}$. In Thrace region, average wheat yield is 529 , sunflower is 238 , canola is 300 and rice is $825 \mathrm{~kg} / \mathrm{da}$. In Table 3, according to the results of the research, the average yields are used to calculate the income and costs of field products (wheat, sunflower, canola and paddy) within the scope of the research. As it can be seen from the table, the yield of wheat, sunflower, canola and paddy produced in Tekirdağ, Edirne and Kırklareli provinces varied according to provinces. However, these differences are not very important. For example; wheat, sunflower and canola yield in was higher in Tekirdag province while the yield of paddy was higher in Edirne province. So, according to survey; the average yields of the provinces were calculated as wheat $508 \mathrm{~kg} / \mathrm{da}$, sunflower 205 $\mathrm{kg} / \mathrm{da}$, canola $346 \mathrm{~kg} / \mathrm{da}$ and $835 \mathrm{~kg} / \mathrm{da}$ paddy in these three cities. 
Table 2. Wheat, sunflower, canola and paddy yield according to the Directorates of Agriculture

\begin{tabular}{lcccccccc}
\hline \multirow{2}{*}{ Cities } & \multicolumn{2}{c}{ Wheat } & \multicolumn{2}{c}{ Sunflower } & \multicolumn{2}{c}{ Canola } & \multicolumn{2}{c}{ Paddy } \\
\cline { 2 - 10 } & Min. & Max. & Min. & Max. & Min. & Max. & Min. & Max. \\
\hline Tekirdağ & 300 & 800 & 100 & 400 & 150 & 500 & 650 & 950 \\
Edirne & 280 & 775 & 120 & 350 & 130 & 450 & 750 & 1000 \\
Kırklareli & 270 & 750 & 105 & 350 & 125 & 450 & 650 & 950 \\
\hline \multirow{2}{*}{ Average } & 283.3 & 775.0 & 108.3 & 366.7 & 135.0 & 466.7 & 683.3 & 966.7 \\
\cline { 2 - 9 } & \multicolumn{2}{c}{529.2} & \multicolumn{2}{c}{237.5} & & 300.1 & 825
\end{tabular}

Source: Anonim, a. 2016.

Table 3. Yields used to calculate income and costs according to survey results

\begin{tabular}{lcccc}
\hline Cities & Wheat & Sunflower & Canola & Paddy \\
\hline Tekirdağ & 543 & 225 & 363 & 825 \\
Edirne & 500 & 200 & 340 & 850 \\
Kırklareli & 480 & 190 & 335 & 830 \\
\hline Average & 507.7 & 205.0 & 346.0 & 835.0 \\
\hline
\end{tabular}

\section{Prices of some products in Thrace region}

In free competition conditions, the prices of the products are formed in the commodity exchanges. Farmers can offer their products for selling to many buyers in the commodity exchanges, so that they can sell their products safely and with the prices close to the real value. In Thrace Region, selling of products are carried out on the commodity exchanges usually. Minimum and maximum Season Prices (TL / kg) in Tekirdağ, Edirne and Kırklareli Commodity Exchanges are shown in Table 4. As can be seen from the table, wheat 0,80 $\mathrm{TL}$, sunflower $1.30 \mathrm{TL}$, canola 1.20 TL and paddy prices in the provinces around $1.50 \mathrm{TL}$ were traded in the stock market. The prices obtained from the surveys and used in the calculation of revenues are given in Table 5. As can be seen from Table 5, wheat producers sold approximately $0,82 \mathrm{TL} / \mathrm{kg}$, Sunflower 1,40 TL/kg, Canola 1,20 TL/kg and Paddy 1,39TL/kg in the market.

Table 4. Prices in Tekirdağ, Edirne and Kırklareli commodity exchanges (TL/ Kg)

\begin{tabular}{lcccccccccc}
\hline \multirow{2}{*}{ Products } & \multicolumn{3}{c}{ Tekirdağ } & \multicolumn{3}{c}{ Edirne } & \multicolumn{3}{c}{ Kırklareli } \\
\cline { 2 - 20 } & Min. & Max. & Avg. & Min. & Max. & Avg. & Min. & Max. & Avg. \\
\hline Wheat & 0.65 & 0.9 & $\mathbf{0 . 7 8}$ & 0.50 & 0.95 & $\mathbf{0 . 7 3}$ & 0.54 & 0.87 & $\mathbf{0 . 7 1}$ \\
Sunflower & 1.35 & 1.4 & $\mathbf{1 . 3 8}$ & 0.80 & 1.9 & $\mathbf{1 . 3 5}$ & 1.10 & 1.55 & $\mathbf{1 . 3 3}$ \\
Canola & 1.15 & 1.25 & $\mathbf{1 . 2 0}$ & 0.89 & 1.50 & $\mathbf{1 . 2 0}$ & 0.92 & 1.30 & $\mathbf{1 . 1 9}$ \\
Paddy & 1.35 & 1.4 & $\mathbf{1 . 3 8}$ & 1.4 & 1.8 & $\mathbf{1 . 6 0}$ & 1.65 & 2.19 & $\mathbf{1 . 9 2}$ \\
\hline
\end{tabular}

Source: Anonim, b. 2016.

Table 5. Average prices used to calculate harvest times and revenues (TL/da)

\begin{tabular}{lcccc}
\hline \multirow{2}{*}{ City / Harvest Time } & Wheat & Sunflower & Canola & Paddy \\
\cline { 2 - 5 } & June-July & August -September & June-July & September-October \\
\hline Tekirdağ & 0.82 & 1.38 & 1.20 & 1.40 \\
Edirne & 0.82 & 1.35 & 1.20 & 1.35 \\
Kırklareli & 0.82 & 1.33 & 1.19 & 1.40 \\
\hline Average & $\mathbf{0 . 8 2}$ & $\mathbf{1 . 4 0}$ & $\mathbf{1 . 2 0}$ & $\mathbf{1 . 3 9}$ \\
\hline
\end{tabular}




\section{Agricultural input supports and premium supports of some products in Thrace region}

In 2016, the Council of Ministers' Decision on Agricultural Supports was made to pay diesel, fertilizer and soil analysis support payments on the basis of the producers involved in the Farmer Registration System (ÇKS). In 2016, farmers provided fertilizer, diesel and soil analysis support as well as premium support. Apart from these, contracted sowing and certified seed support have also been applied. But these supports have not been used for the calculation of incomes, since they are not included in every farmer. In Table 6, the amounts of subsidies announced by the Council of Ministers for the 2016 production year are given. In the 2016 production year, a payment of $2.5 \mathrm{TL} / \mathrm{da}$ for soil analysis, 4,6 TL/da diesel support and 6 $\mathrm{TL} / \mathrm{da}$ fertilizer support for wheat and paddy were paid (Table 6). In the "Decision on the Determination of the Agricultural Basins of Turkey", 30 different agriculture bases have been adopted to pay premiums (premiums) to the products produced and sold in the 2016 production season. According to this, support for different payments per kilogram were decided as 0,30 TL/da for sunflower, $0,55 \mathrm{TL} / \mathrm{da}$ for wheat, $0,50 \mathrm{TL} / \mathrm{da}$ for soybeans, 0,40 TL/da for canola, 0,40 TL/da for corn, 0,45 TL/da for aspir, 0,70 TL/da for olive oil, 12 $\mathrm{TL} / \mathrm{da}$ for tea were (Table 7). Premium subsidy amounts which were calculated for income and costs and are shown in Table 6. For example, when the wheat yield is $523 \mathrm{~kg} / \mathrm{da}$, the premium amount $(523 \times 0.05)$ used by the enterprises is calculated as $26,2 \mathrm{TL} /$ da in the province of Tekirdağ (Table 7).

The total value (premium + other supports) of the supporting amounts that the enterprises used was calculated in TL/da and shown in Table 8. As you can see from the chart; Total support amounts were calculated as $39.0 \mathrm{TL} /$ da for wheat, 82.0 for sunflower, 157.5 for canola and $95.6 \mathrm{TL} / \mathrm{da}$ for paddy in Tekirdağ.

Table 6. Agricultural input supports

\begin{tabular}{lcccc}
\hline Supports & Wheat & Sunflower & Canola & Paddy \\
\hline Premium support (krs/kg) & 5 & 30 & 40 & 10 \\
Fertilizer support (TL/da) & 6 & 7.5 & 7.5 & 6 \\
Diesel support (TL/da) & 4.6 & 7.5 & 7.5 & 4.6 \\
Soil analysis support (TL/da) & 2.5 & 2.5 & 2.5 & 2.5 \\
\hline
\end{tabular}

Source: https://www.tarim.gov.tr/TAGEM/Belgeler/ar_ge_projeleri/bakanlar_kurulu_karari.pdf. Note: Contracted sowing support $(15 \mathrm{TL} / \mathrm{da})$ was excluded in calculations.

Table 7. Premium support quantities calculated by yields (TL/da)

\begin{tabular}{lccccc}
\hline Cities & Wheat & Sunflower & Canola & Paddy & Average \\
\hline Tekirdağ & 26.2 & 64.5 & 140.0 & 82.5 & 78.3 \\
Edirne & 25.0 & 60.0 & 136.0 & 85.0 & 76.5 \\
Kırklareli & 24.0 & 57.0 & 134.0 & 83.0 & 74.5 \\
\hline
\end{tabular}

Table 8. Total supporting amount of businesses (TL/da)

\begin{tabular}{lccccc}
\hline Supports by products and cities & Wheat & Sunflower & Canola & Paddy & Average \\
\hline Total of other supports & 13.1 & 17.5 & 17.5 & 13.1 & 15.3 \\
Total support (Tekirdağ) & 39.3 & 82.0 & 157.5 & 95.6 & 93.6 \\
Total support (Edirne) & 38.1 & 77.5 & 153.5 & 98.1 & 91.8 \\
Total support (Kırklareli) & 37.1 & 74.5 & 151.5 & 96.1 & 89.8 \\
\hline Average & 38.2 & 78.0 & 154.2 & 96.6 & 91.7 \\
\hline
\end{tabular}




\section{The share of the supports in the Thrace region from the grain}

Table 9 shows the share of the supports according to crop varieties in the Thrace Region. As seen from the table, total support amount was 38,2 $\mathrm{TL} / \mathrm{da}$ in Turkey in general and the share of support in income $30,6 \%$ for wheat.

The total amount of subsidies for sunflower was about 78,0 TL/da and the share of it in income was $103,2 \%$. it was determined that the highest share was $103.2 \%$ and the lowest share was $27.9 \%$. The most important reason for this was that, sunflower had a lower total cost of production than other crops. When the share of the subsidies within the incomes obtained from the crops was classified according to the size of the enterprises in the Thrace Region, different results occured.
Table 10 shows the Share of supports of revenues in Thrace Region according to farm size and yields. As seen from the table, the support amounts are not enough for wheat farmers in first group. The share is calculated $-730,2 \%$ meaninglessly.

The farmers in first group need more sufficient support amounts. But in second group, it was determined that $43,4 \%$ of income came from supports. The biggest support was given to canola farm according to calculations.

Table 9. The share of the supports according to crop varieties in the Thrace Region

\begin{tabular}{|c|c|c|c|c|}
\hline Elements & Wheat & Sunflower & Canola & Paddy \\
\hline Total variable costs (TL/da) & 238.4 & 179.8 & 262.4 & 617.5 \\
\hline Total fixed costs (TL/da) & 109.1 & 107.3 & 109.8 & 287.1 \\
\hline Total production costs (TL/da) & 347.4 & 287.2 & 372.2 & 904.6 \\
\hline Main product yield (kg/da) & 507.7 & 201.7 & 346.0 & 835.0 \\
\hline Main product price (TL/kg) & 0.8 & 1.4 & 1.2 & 1.38 \\
\hline Main product amount (TL/kg) & 416.3 & 278.0 & 414.1 & 1155.08 \\
\hline By-product amount (TL/kg) & 17.9 & - & - & - \\
\hline GPV* (TL/da) (Excluding supports) & 434.2 & 273.1 & 414.0 & 1155.0 \\
\hline Total support amount (TL/da) & 38.2 & 78.0 & 154.2 & 96.6 \\
\hline Total GPV (TL/da) (Supports included) & 472.3 & 356.5 & 562.4 & 1251.4 \\
\hline Gross profit (TL/da) (Excluding supports) & 195.8 & 98.7 & 151.5 & 537.3 \\
\hline Net profit (TL/da) (Excluding supports ) & 86.7 & -7.3 & 42.0 & 250.2 \\
\hline Net Profit (TL/da) (Supports included) & 124.9 & 75.6 & 196.1 & 346.8 \\
\hline Share of support in income (\%) & 30.6 & 103.2 & 78.6 & 27.9 \\
\hline
\end{tabular}

*GPV: Gross Product Value 
Table 10. Share of supports of revenues in Thrace Region (according to farm size and yields)

\begin{tabular}{|c|c|c|c|c|c|c|}
\hline \multirow{2}{*}{ Crops } & \multirow{2}{*}{ Factors } & \multirow{2}{*}{$\frac{\text { 1.Group }}{(50-100 \mathrm{da})}$} & \multirow{2}{*}{$\frac{\text { 2.Group }}{(101-250 \mathrm{da})}$} & \multirow{2}{*}{$\frac{\text { 3.Group }}{(251-500 \mathrm{da})}$} & \multirow{2}{*}{$\begin{array}{c}\text { 4.Group } \\
\text { (501 da >) }\end{array}$} & \multirow{2}{*}{ Total } \\
\hline & & & & & & \\
\hline \multirow{4}{*}{$\frac{\stackrel{+}{d}}{\stackrel{2}{3}}$} & Total support amount (TL/da) & 31.4 & 36.2 & 39.4 & 45.7 & 38,2 \\
\hline & Net profit (TL/da) (Excluding supports) & -35.8 & 47.7 & 115.3 & 256.9 & 86,7 \\
\hline & Net profit (TL/da) (Supports included) & -4.3 & 83.8 & 154.7 & 302.6 & 124,9 \\
\hline & Share of support (\%) & -730.2 & 43.4 & 25.5 & 15.1 & 30,6 \\
\hline \multirow{4}{*}{ 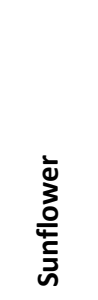 } & Total support amount (TL/da) & 62.8 & 75.0 & 83.3 & 90.9 & 78,0 \\
\hline & Net profit (TL/da) (Excluding supports) & -62.3 & -9.9 & -4.9 & 28.3 & $-7,3$ \\
\hline & Net Profit (TL/da) (Supports included) & -19.6 & 40.4 & 49.4 & 89.6 & 75,6 \\
\hline & Share of support (\%) & -320.4 & 185.6 & 168.6 & 101.5 & 103,2 \\
\hline \multirow{4}{*}{$\begin{array}{l}\frac{\pi}{0} \\
\frac{1}{5} \\
\text { UN }\end{array}$} & Total Support Amount (TL/da) & 190.3 & 239.5 & 267.1 & 288.2 & 154,2 \\
\hline & Net profit (TL/da) (Excluding supports) & -2.9 & 98.8 & 96.3 & 122.3 & 42,0 \\
\hline & Net profit (TL/da) (Supports included) & 25.9 & 162.1 & 172.8 & 214.2 & 196,1 \\
\hline & Share of support (\%) & 735.0 & 147.5 & 154.6 & 134.5 & 78,6 \\
\hline \multirow{4}{*}{$\begin{array}{l}\frac{7}{0} \\
\frac{0}{0} \\
0\end{array}$} & Total support amount (TL/da) & 79.1 & 95.7 & 100.9 & 110.6 & 96,6 \\
\hline & Net profit (TL/da) (Excluding supports) & 48.7 & 248.2 & 282.6 & 409.1 & 250,2 \\
\hline & Net Profit (TL/da) (Supports included) & 127.8 & 343.9 & 383.5 & 519.7 & 346,8 \\
\hline & Share of support (\%) & 61.9 & 29,3 & 26.3 & 21.3 & 27,9 \\
\hline
\end{tabular}

\section{Conclusions}

In this study, the share of field crop subsidies in farm income was examined in the Thrace Region. A number of agricultural input subsidies such as premium, fertilizer, diesel and soil analysis announced by the Council of Ministers were taken into consideration for calculations.

In the survey, subsidy amounts were calculated using the yields per. As seen from the calculations, support share in income of farmers varies according to farm sizes and crops at the same time. For example, it was determined that the maximum amount of premiums that enterprises used was in canola and the lowest amount in wheat production.

Farmers benefited from the total amount of support at a maximum rate 154,2 TL/da in canola and minimum $38.2 \mathrm{TL} / \mathrm{da}$ in wheat.

When the shares of the subsidies in the incomes were examined by crop varieties, the maximum share was found for sunflower (103,2 \%) and the minimum for paddy $(27,9 \%)$.

It was determined that the share of the products varies according farm size also. It has been found that wheat and sunflower farmers in the 1st group, which have a size of 50-100, needed more support than existed. Calculations showed that they were not supported adequately. But in the same group, as seen from the table 10 , canola farmers were benefited at a maximum rate.

As a result of this study, it can be easily said that grain products in the Thrace region are not adequately supported. It was determined that especially the small size enterprises couldn't benefit from subsidies sufficiently. However, adequate support and payments on time have vital importance for farmers. Input costs and farm sizes has to take into consideration for agricultural policy implements. The general view shows as bigger land owners has more benefit than small land owners in agricultural sector. Especially if small farmers do not 
get enough support, they may come to the point of leaving agriculture and this will also result in an increase in migration from the village to the cities. That's why, the agricultural policies should be determined by considering farm size and the costs of crops.

\section{References}

Anonymous, 2016a. Tekirdağ, Edirne and Kırklareli, Records of Provincial Directorates of Agriculture.

https://www.tarim.gov.tr/TAGEM/Belgeler/ ar_ge_projeleri/bakanlar_kurulu_karari.pdf. Anonymous, 2016b. Tekirdağ, Edirne and Kırklareli, Records of Commodity Changes. http://www.bumko.gov.tr.

Bayraktar, Y., Bulut, E., 2016. Tarımsal desteklerin değişen yapısı ve yüksek tarımsal desteklerin nedenleri: Türkiye için karşılaştırmalı bir analiz. İktisat Fakültesi Mecmuası, 66(1): 4566.

Burfish, E.M., Hopkins, J. 2003. Decoupled Payments: Household Income Transfers in Contemporary United States Agriculture. Market and Trade, Economics Division, Economic Research Service, U.S. Department of agriculture, Agricultural Economic Report, No: 822.

Goodwin, K., Mishra, H., Kimhi, A. 2007. Household Time Allocation and Endogenous Farm Structure: Implications for the Design of Agricultural Policies. The Hebrew University of Jerusalem, Discussion Paper No: 11.07, pp. 1-37.

Tuncer, M., Günay, H.F. 2017. Türkiye'de tarıma yönelik desteklerin Avrupa Birliği perspektifinden değerlendirilmesi. Avrasya Sosyal ve Ekonomi Araştırmaları Dergisi 4(8): 15-30.

TURKSTAT, 2017. www.turkstat.gov.tr.

Weber, G.J., Key, N. 2012. "How much do decoupled payments affect production? An instrumental variable approach with panel data". American Journal of Agricultural Economics, 94(1): 52-66.

Yılmaz, S., Yılmaz, İ., Özkan, B. 1999. Türkiye'de uygulanan girdi kullanımı teşvik politikaları. Akdeniz Üniversitesi Ziraat Fakültesi Dergisi, 12(1): 183-194. 